\title{
Soil carbon stock in different land-use systems in the hilly terrain of Mizoram, Northeast India
}

\author{
Chowlani Manpoong* \\ Faculty of Agricultural Sciences, Arunachal University of Studies, Namsai-792103 (Arunachal \\ Pradesh), India \\ Wapongnungsang \\ Department of Forest Science, Nagaland University, Lumami-798627 (Nagaland), India \\ S. K. Tripathi \\ Department of Forestry, School of Earth Sciences and Natural Resources Management, \\ Mizoram University, Aizawl-796004 (Mizoram), India \\ * Corresponding author. E-mail: chowlani18@gmail.com
}

\section{How to Cite}

Manpoong, C. et al. (2021). Soil carbon stock in different land-use systems in the hilly terrain of Mizoram, Northeast India. Journal of Applied and Natural Science, 13(2), 723 - 728. https://doi.org/10.31018/jans.v13i2.2615

\section{Abstract}

Soil carbon is one of the most affected variables to land-use change in tropics. The soil carbon flux plays a major role in regulating microbial activities and nutrient distribution in soil. This study aimed to evaluate the soil carbon stock in various land uses at different depths in the hilly terrain of Mizoram, Northeast India. Soil samples at 0-10 cm, 10-20 cm and 20-30 cm soil depths were collected from Rubber plantation (RP), Oil palm plantation (OPP), Teak plantation (TP), Bamboo Forest (BF), 5 years fallow (5YF), 10 years fallow (10YF), Tephrosia candida plantation (TCP), Horticulture garden (HORT), Homegarden (HG) and Natural forest (NF). Soil carbon stock varied significantly $(p<0.05)$ across the land uses and depths. The soil under Tephrosia candida stand had significantly $(p<0.05)$ higher values of $C$ stock $\left(73.66 \mathrm{Mg} \mathrm{ha}^{-1}\right)$ which may be due to high biomass, dense vegetative cover and high $C$ in root exudates. The minimum $C$ stock estimated in Horticulture garden $\left(43.28 \mathrm{Mg} \mathrm{ha}^{-1}\right)$ is probably due to reduced soil organic matter. Soil carbon stock in Homegarden, Teak plantation, Bamboo forest and Rubber plantation ranged from $46.82 \mathrm{Mg} \mathrm{ha}^{-1}$ to $59.34 \mathrm{Mg} \mathrm{ha}^{-1}$ whereas 5 years and 10 years fallow land, Natural forest and Oil palm plantation ranged from $61.35 \mathrm{Mg} \mathrm{ha}^{-1}$ to $73.35 \mathrm{Mg} \mathrm{ha}^{-1}$. The study indicated that the land use change in the mountainous region significantly affected the carbon stock in the soil. A proper land use management strategies to increase the soil organic matter is recommended to enhance the carbon stock in this region.
\end{abstract}

Keywords: Land-use change, Mountainous region, Northeast India, Soil carbon stock, Soil depth

\section{INTRODUCTION}

Soil carbon is an important component of the global carbon cycle indicating soil fertility and productivity (Van der Werf et al., 2009) and worldwide studies have shown a significant variation with relation to land uses (Ali et al., 2017; Iqbal et al., 2014; Maurya et al., 2014). It is estimated that almost $60 \%$ of the world's terrestrial carbon is stored in forest vegetation and soil (McKinley et al., 2011). 38\% of the organic carbon is stored in the soil of tropical forests whereas $72 \%$ is found in soils of northern forests (Blais et al., 2005). However, the growing population has drastically changed the land use pattern in tropical forests to meet their food and timber demands. Conversion of cropland to pasture land, tree plantation and secondary forest has shown a significant increase in soil carbon stock (Guo and Gifford, 2002). Losses in soil carbon caused by the conversion of natural to cultivated vegetation are well documented (Manpoong and Tripathi, 2019; Yan et al., 2012). Globally, $24 \%$ of the soil carbon is lost through forest conversion to cropland (Wei et al., 2014).

Mizoram is a steeply sloped mountainous region with a geographical area of $21,087 \mathrm{~km}^{2}$ covering $86.27 \%$ forest and ranked second largest forest cover with respect to its geographical area in the country (Forest Survey Report, 2017). Land -use change is one of the major change processes and has altered the structure and functioning of forest ecosystems in the region. Tropical and subtropical forests of Mizoram are significantly shrinking due to change in land use pattern, particularly shifting cultivation and plantations which pro- 
foundly affects soil properties (Manpoong and Tripathi, 2019; Ovung et al., 2020). An increase in forest cover in certain areas is due to regeneration of bamboo species and other plantations (Forest Survey Report, 2017). A large extent of natural forest has turned up for Oil Palm and Rubber plantations as per land capability, suitability and sloppy terrain of the region (Economic survey Mizoram, 2016-2017).

Since, the land-use types affect the amount of litter input and the rate of decomposition (Lehmann et al., 2000), assessing soil as carbon sink in different land use systems, including forest ecosystem is important prior to land use management. Understanding the impact of land-use change on carbon stock is essential for effective land use planning and mitigation of climate change in the ecologically highly vulnerable hilly terrain of Mizoram. Thus, the present study aimed to assess the soil carbon stock in different land-use systems of hilly terrain of Mizoram.

\section{MATERIALS AND METHODS}

\section{Study area}

The studied land-use systems were situated in the northern part of Mizoram between $24^{\circ} 25^{\prime} 16^{\prime \prime}$ and $23^{\circ} 18^{\prime} 11^{\prime \prime} N$ Latitudes and $92^{\circ} 37^{\prime} 03^{\prime \prime}$ and $93^{\circ} 11^{\prime} 45^{\prime \prime} \mathrm{E}$ Longitudes (Fig. 1). Mizoram constituting $0.64 \%$ of the country's geographical area comprises rugged, steep hill ranges and interspersed valleys. The state has different forest types belonging to 4 groups Tropical semievergreen, Tropical moist deciduous, Subtropical broadleaved hill and Subtropical Pine forests and is a part of Indo-Burma bio-geographic region, which is one of the richest biodiversity hotspots of the world. The state experiences the moist tropical to moist subtropical climate. During winter, the temperature varies from $11^{\circ} \mathrm{C}$ to $24^{\circ} \mathrm{C}$ and during summer it varies between $18^{\circ} \mathrm{C}$ to $29^{\circ} \mathrm{C}$. The total annual rainfall varies from $2160 \mathrm{~mm}$ to $3500 \mathrm{~mm}$. In terms of forest canopy density classes, the state has $131 \mathrm{sq} \mathrm{km}$ under very dense forest, 5861 $\mathrm{km}^{2}$ under moderately dense forest and 12, $194 \mathrm{~km}^{2}$ under open forest. The total carbon stock of forests in the state is 95.041 million tonnes $(348.484$ million tonnes of $\mathrm{CO}_{2}$ equivalent) which is $1.34 \%$ of the total forest carbon of the country (Forest Survey Report, 2017).

\section{Soil sampling}

The soil samples were collected from 10 land uses: Rubber plantation (RP), Oil palm plantation (OPP), Teak plantation (TP), Bamboo Forest (BF), 5 years fallow (5YF), 10 years fallow (10YF), Tephrosia candida plantation (TCP), Horticulture garden (HORT), Homegarden (HG) and Natural forest (NF) to determine the variation in soil carbon (C) stock across different land use systems. Three sample plots of $20 \mathrm{~m} \times 20 \mathrm{~m}$ were randomly selected in each land-use system with five random sampling points in each sample plots. The vegetation, litter, roots, stones, and debris if any were removed from the surface of the sampling point. Soil samples were taken from three depths $(0-10,10-20$ and $20-30 \mathrm{~cm}$ ) to make a composite sample for each horizon. In this way, three composite replicates samples were taken from each land use. These samples were brought to the laboratory and then air-dried. The dried samples were lightly ground, sieved through a 2 $\mathrm{mm}$ mesh sieve and used to analyse soil organic carbon.

An undisturbed core sample was also collected from each plot at three depths $(0-10,10-20$ and $20-30 \mathrm{~cm})$ to estimate the bulk density by using a core ring and was packed in polyethylene bags and labeled.

\section{Soil analysis}

Soil C was analyzed by Walkley-Black chromic acid wet oxidation method (1934). Bulk density was determined by the core method described by Blake and Hartge (1986). The samples were oven-dried at $105^{\circ} \mathrm{C}$ for 24 hrs to constant weight and the oven-dry weight of the sample was divided by its volume in cubic centimeters to calculate the bulk density of the soil. The soil samples were then dry sieved and weighed to obtain $<2$ $\mathrm{mm}$ size fractions and $>2 \mathrm{~mm}$ rock fragments. The soil C stock $\left(\mathrm{Mg} \mathrm{ha}^{-1}\right)$ was calculated by multiplying the soil C concentration (\%) with the calculated bulk density ( $\mathrm{g}$ $\mathrm{cm}^{-1}$ ) and depth of soil layer $(\mathrm{cm})$ by using the following formula described by Batjes (1996).

Soil C stock $\left(\mathrm{Mg} \mathrm{ha}^{-1}\right)=$ soil $\mathrm{C}(\%) \times \mathrm{BD}\left(\mathrm{g} \mathrm{cm}^{-1}\right) \times$ soil depth $(\mathrm{cm}) \times(1-\mathrm{F}) \quad$..... Eq. 1 where,

$F$ is the volume of the fraction of fragments $>2 \mathrm{~mm}$ BD-Bulk density

\section{Statistical analysis}

An analysis of variance was carried out to determine the effect of land use on bulk density, soil $C$, and soil $C$ stock at different soil depths. A least significant difference (LSD) comparison test was done to separate statistically different means $(p<0.05)$. SPSS version 18.0 (SPSS Inc., Chicago, IL) was used for the statistical analysis.

\section{RESULTS AND DISCUSSION}

\section{Effect of land-use change on soil carbon}

Soil C differed significantly $(p<0.05)$ between land-use types at all the studied soil depths (Table 1). Soil C concentration was maximum in NF which was followed in decreasing order by TCP > $5 \mathrm{YF}>\mathrm{OPP}>10 \mathrm{YF}>$ $\mathrm{RP}>\mathrm{BF}>\mathrm{HG}>\mathrm{HORT}>\mathrm{TP}$. The magnitude and direction of soil $C$ dynamics are gradually affected by multiple factors, including climate, soil type, soil depth, 


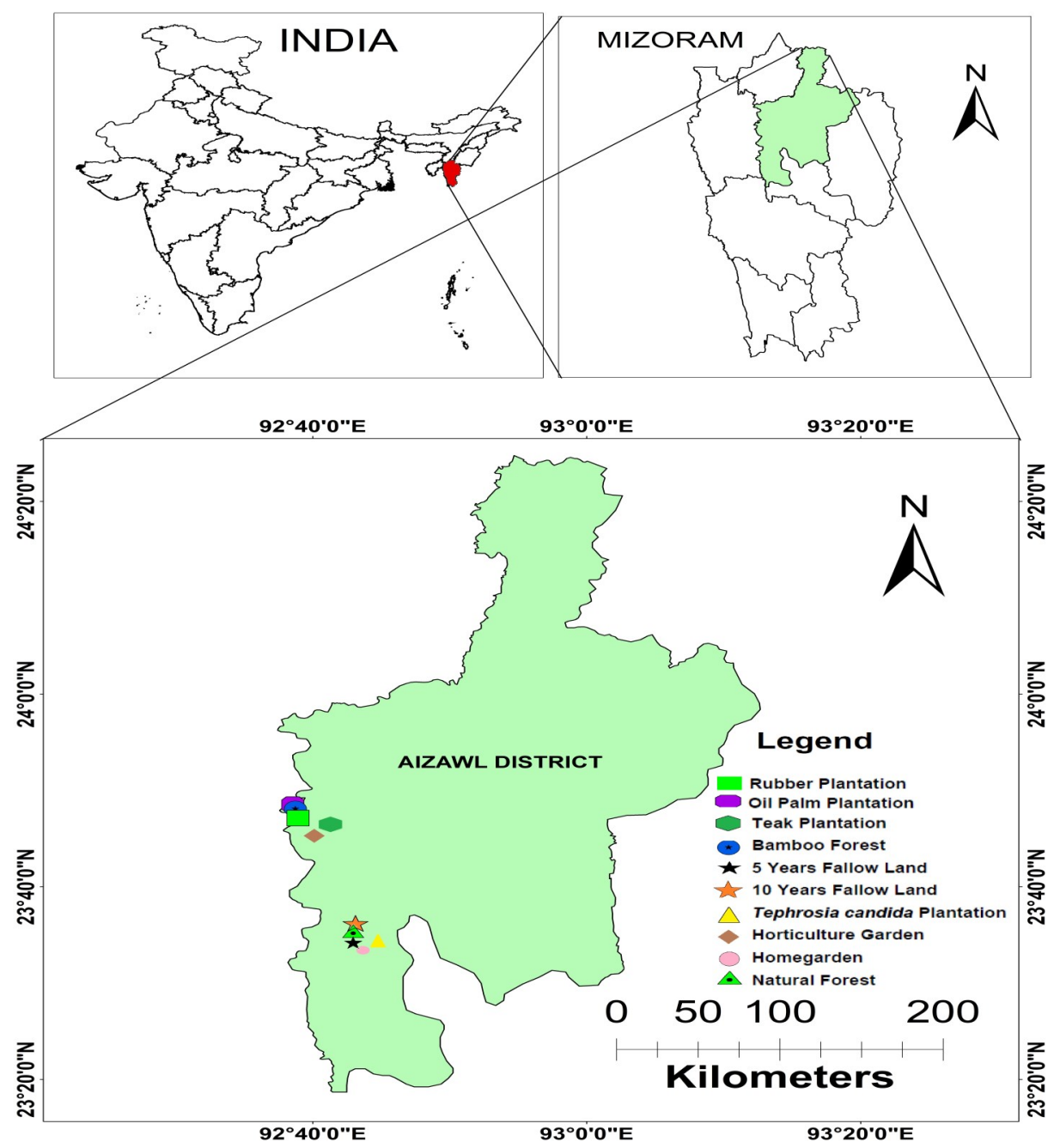

Fig. 1. Map of study area of Aizawl District of Mizoram.

tree species, nutrient management and vegetation (Don et al., 2011; Wapongnungsang et al., 2018). Higher soil $\mathrm{C}$ in NF could be due to the greater biomass input through vegetation as soil organic matter generally has a positive relationship with plant density. The reduced inputs of $\mathrm{C}$ into the soil compared to the native land use subsequently increases the rate of soil organic matter decomposition, which possibly led to a net loss of soil $C$ in other land uses. Similar findings have been reported during the conversion of farmland to the plantation, secondary forests and grasslands of China by Zhang et al. (2010).

\section{Effect of land-use change on soil $\mathbf{C}$ stock}

The soil $C$ stock was found maximum in TCP which was followed by OPP > $10 \mathrm{YF}>\mathrm{NF}>5 \mathrm{YF}>\mathrm{RP}>\mathrm{BF}$ $>\mathrm{TP}>\mathrm{HG}>\mathrm{HORT}$ (Table 1). Conversion of NF led to sharp decrease of $\mathrm{C}$ stock in $5 \mathrm{YF}, \mathrm{RP}, \mathrm{BF}, \mathrm{TP}, \mathrm{HG}$ and HORT $(8.8 \%, 11.8 \%, 29.4 \%, 30.3 \%, 30.4 \%$ and $35.7 \%$ respectively). Comparatively, there was a small increase in soil $\mathrm{C}$ stock in $10 \mathrm{YF}$, OPP and TCP (3\%, $8.9 \%$ and $9.4 \%$, respectively) with the change in land use. Guo and Gifford, (2002) also reported a decline in soil $\mathrm{C}$ stocks after land use changes from pasture to plantation $(-10 \%)$, native forest to plantation $(-13 \%)$, native forest to crop $(-42 \%)$, and pasture to crop $(-59 \%)$. Significant differences of soil $\mathrm{C}$ stock between land uses could be due to the variation in quality and quantity of aboveground biomass (which led to different C concentrations) as well as variation in soil bulk density under different land use systems. The maximum soil C stock in TCP is possibly due to high biomass, dense vegetative cover, high $C$ in root exudates and a deep root system with high nitrogen fixing ability (Manpoong et al., 2020a). Tephrosia candida plantation has played a vital role in restoring degraded land and shifting cultivation sites to enhance soil fertility and crop productivity (Wapongnungsang et al., 2017). A distinct increase in soil $C$ stock was recorded in 10 years fallow compared to 5 years of fallow land. This could be attributed to the progressive accumulation of soil organic matter and the recovery of soil microbial communities with the increase in the fallow period (Wapongnungsang et al., 2018; Manpoong et al., 2020b). A longer fallow period 
Manpoong, C. et al. / J. Appl. \& Nat. Sci. 13(2), 723 - 728 (2021)

Table 1. Soil C stock $\left(\mathrm{Mg} \mathrm{ha}^{-1}\right)$ in different land-use systems. LSD is shown at $p<0.05$.

\begin{tabular}{|c|c|c|c|c|}
\hline Land-use system & Depths & Soil carbon $\%$ & Bulk density $\left(\mathrm{g} \mathrm{cm}^{-3}\right)$ & Soil C stock $\left(\mathrm{Mg} \mathrm{ha}^{-1}\right)$ \\
\hline \multirow{4}{*}{ Rubber Plantation } & $0-10 \mathrm{~cm}$ & 1.62 & 1.33 & 21.43 \\
\hline & $10-20 \mathrm{~cm}$ & 1.43 & 1.40 & 19.94 \\
\hline & $20-30 \mathrm{~cm}$ & 1.23 & 1.47 & 17.97 \\
\hline & $\begin{array}{l}0-30 \mathrm{~cm} \\
\text { LSD }\end{array}$ & $\begin{array}{l}1.42 \\
\mathbf{0 . 2 0}\end{array}$ & $\begin{array}{l}1.40 \\
\mathbf{0 . 0 4}\end{array}$ & $\begin{array}{l}59.34 \\
2.93\end{array}$ \\
\hline \multirow{5}{*}{ Oil Palm Plantation } & $0-10 \mathrm{~cm}$ & 2.15 & 1.25 & 26.96 \\
\hline & $10-20 \mathrm{~cm}$ & 1.91 & 1.36 & 25.99 \\
\hline & $20-30 \mathrm{~cm}$ & 1.46 & 1.40 & 20.40 \\
\hline & $0-30 \mathrm{~cm}$ & 1.84 & 1.34 & 73.35 \\
\hline & LSD & 0.17 & 0.08 & \\
\hline \multirow{5}{*}{ Teak Plantation } & $0-10 \mathrm{~cm}$ & 1.08 & 1.30 & 14.00 \\
\hline & $10-20 \mathrm{~cm}$ & 1.04 & 1.53 & 15.87 \\
\hline & $20-30 \mathrm{~cm}$ & 1.01 & 1.69 & 17.00 \\
\hline & $0-30 \mathrm{~cm}$ & 1.04 & 1.50 & 46.87 \\
\hline & LSD & 0.34 & 0.17 & 5.6 \\
\hline \multirow{5}{*}{ Bamboo Forest } & $0-10 \mathrm{~cm}$ & 1.53 & 1.08 & 16.51 \\
\hline & $10-20 \mathrm{~cm}$ & 1.33 & 1.26 & 16.64 \\
\hline & $20-30 \mathrm{~cm}$ & 1.03 & 1.39 & 14.32 \\
\hline & $0-30 \mathrm{~cm}$ & 1.30 & 1.24 & 47.47 \\
\hline & LSD & 0.33 & 0.03 & 4.36 \\
\hline \multirow{4}{*}{5 years Fallow } & $0-10 \mathrm{~cm}$ & 2.26 & 0.90 & 20.37 \\
\hline & $10-20 \mathrm{~cm}$ & 2.16 & 1.04 & 22.47 \\
\hline & $20-30 \mathrm{~cm}$ & 1.63 & 1.14 & 18.51 \\
\hline & $\begin{array}{l}0-30 \mathrm{~cm} \\
\text { LSD }\end{array}$ & $\begin{array}{l}2.01 \\
0.16\end{array}$ & $\begin{array}{l}1.03 \\
\mathbf{0 . 1 4}\end{array}$ & $\begin{array}{l}61.35 \\
1.99\end{array}$ \\
\hline \multirow{4}{*}{10 years Fallow } & $0-10 \mathrm{~cm}$ & 1.99 & 1.04 & 20.65 \\
\hline & $10-20 \mathrm{~cm}$ & 1.80 & 1.36 & 24.57 \\
\hline & $20-30 \mathrm{~cm}$ & 1.67 & 1.44 & 24.13 \\
\hline & $\begin{array}{l}0-30 \mathrm{~cm} \\
\text { LSD }\end{array}$ & $\begin{array}{l}1.82 \\
0.23\end{array}$ & $\begin{array}{l}1.28 \\
0.20\end{array}$ & $\begin{array}{l}69.36 \\
5.85\end{array}$ \\
\hline \multirow{4}{*}{$\begin{array}{l}\text { Tephrosia candida Planta- } \\
\text { tion }\end{array}$} & $0-10 \mathrm{~cm}$ & 2.37 & 1.09 & 25.68 \\
\hline & $10-20 \mathrm{~cm}$ & 2.24 & 1.16 & 25.99 \\
\hline & $20-30 \mathrm{~cm}$ & 1.80 & 1.22 & 21.99 \\
\hline & $\begin{array}{l}0-30 \mathrm{~cm} \\
\text { LSD }\end{array}$ & $\begin{array}{l}2.14 \\
0.22\end{array}$ & $\begin{array}{l}1.16 \\
0.15\end{array}$ & $\begin{array}{l}73.66 \\
7.05\end{array}$ \\
\hline \multirow{4}{*}{ Horticulture garden } & $0-10 \mathrm{~cm}$ & 1.19 & 1.17 & 13.97 \\
\hline & $10-20 \mathrm{~cm}$ & 1.18 & 1.24 & 14.34 \\
\hline & $20-30 \mathrm{~cm}$ & 1.08 & 1.38 & 14.97 \\
\hline & $\begin{array}{l}0-30 \mathrm{~cm} \\
\text { LSD }\end{array}$ & $\begin{array}{l}1.15 \\
\mathbf{0 . 1 9}\end{array}$ & $\begin{array}{l}1.27 \\
\mathbf{0 . 4 2}\end{array}$ & $\begin{array}{l}43.28 \\
4.17\end{array}$ \\
\hline \multirow{4}{*}{ Homegarden } & $0-10 \mathrm{~cm}$ & 1.43 & 1.24 & 17.72 \\
\hline & $10-20 \mathrm{~cm}$ & 1.10 & 1.38 & 15.16 \\
\hline & $20-30 \mathrm{~cm}$ & 0.97 & 1.43 & 13.94 \\
\hline & $\begin{array}{l}0-30 \mathrm{~cm} \\
\text { LSD }\end{array}$ & $\begin{array}{l}1.17 \\
0.17\end{array}$ & $\begin{array}{l}1.35 \\
0.20\end{array}$ & $\begin{array}{l}46.82 \\
3.39\end{array}$ \\
\hline \multirow{4}{*}{ Natural Forest } & $0-10 \mathrm{~cm}$ & 2.42 & 0.92 & 22.25 \\
\hline & $10-20 \mathrm{~cm}$ & 2.21 & 0.99 & 21.88 \\
\hline & $20-30 \mathrm{~cm}$ & 1.95 & 1.19 & 23.18 \\
\hline & $\begin{array}{l}0-30 \mathrm{~cm} \\
\text { LSD }\end{array}$ & $\begin{array}{l}2.19 \\
\mathbf{0 . 1 3} \\
\end{array}$ & $\begin{array}{l}1.03 \\
\mathbf{0 . 0 8} \\
\end{array}$ & $\begin{array}{l}67.31 \\
1.40 \\
\end{array}$ \\
\hline \multicolumn{3}{|c|}{$\begin{array}{l}\text { leads to the recovery of original soil status, with a grad- } \\
\text { ual increase in soil C and improved microbial structure } \\
\text { (Aboim et al., 2008). Similarly, Laganiere et al. (2010) } \\
\text { reported that with an increase in time, there is an in- } \\
\text { crease in the quantity of carbon inputs, accompanied } \\
\text { by a new microclimatic regime and enhanced organic } \\
\text { matter that promotes C accumulation in the soil. The }\end{array}$} & \multicolumn{2}{|c|}{$\begin{array}{l}\text { lowest soil C stock in TP, HG and HORT could be due } \\
\text { to low organic matter inputs through the existing vege- } \\
\text { tation. Several workers have reported that natural for- } \\
\text { ests store more carbon than any other terrestrial eco- } \\
\text { system, thereby representing a significant carbon pool } \\
\text { for the global carbon budget (Manpoong and Tripathi, } \\
\text { 2019; Yang et al., 2018; Haghdoost et al., 2013). Re- }\end{array}$} \\
\hline
\end{tabular}


cently, Singh et al. (2018) reported the highest soil C stock in agroforestry land use (50.85 $\mathrm{Mg} \mathrm{C} \mathrm{ha}^{-1}$ ) and the lowest in agricultural cropland (33.99 $\mathrm{Mg} \mathrm{C}^{-1}$ ) when compared with forest and plantations of Mizoram.

\section{Effect of soil depth and land-use on soil $C$ and soil C stock}

Soil $\mathrm{C}$ decreased with depth and bulk density increases with depth, whereas varied trends were observed in soil C stock (Table 1). The highest soil $C$ at upper depth can be attributed to the continuous addition of organic debris, partially decomposed plant and animal remains and micro faunal population in the top soils. Several workers have reported that the upper soil horizon accumulates the maximum organic materials than the deeper horizon (Wang et al., 2008; Emiru and Gebrekidan, 2013).

Soil $C$ stock in RP, OPP and HG decreased with increasing depth whereas in BF, 5 YF, $10 \mathrm{YF}, \mathrm{TCP}$ the maximum soil $C$ stock was found at $10-20 \mathrm{~cm}$ depth. In the present study soil $C$ stock at different depths was found to be very sensitive to land use types. Maximum soil $\mathrm{C}$ stock in RP, OPP and HG at upper depth suggested that the surface soil is more active for sequestering $\mathrm{C}$ from the atmosphere after the land use change. Haghdoost et al. (2013) reported the same trend during conversion of natural forest to other landuses in northern Iran and interpreted to occur as a result of slow litter decomposition and humus conversion that starts from the soil surface.

The maximum soil $\mathrm{C}$ stock at $10-20 \mathrm{~cm}$ depth in jhum fallow lands is possibly due to crop diversification's long -term effect during shifting cultivation that causes differences in quality of aboveground litter inputs and decomposition. The alteration in decomposition dynamics due to diversifying crops in agricultural systems has been reported by McDaniel et al. (2016). Arevalo et al. (2009) argued that about $60 \%$ of soil $\mathrm{C}$ in tropical soils is stored within $0-15 \mathrm{~cm}$ soil depth. However, TP, HORT and NF recorded the maximum soil $\mathrm{C}$ stock at 20-30 cm soil depth, possibly due to higher bulk densities. The study on forest plantation in eastern Australia showed that carbon accumulation and loss patterns also vary according to location, tree species and plantation management system (Turner et al., 2005). In addition, changes in temperature and precipitation pattern may also have a major influence on the decomposition and amount of soil C stored within tropical ecosystems.

\section{Conclusion}

Land use and soil depth had a significant $(p<0.05)$ impact on bulk density, soil $\mathrm{C}$ concentration and soil $\mathrm{C}$ stock. Soil $\mathrm{C}$ was negatively correlated with bulk densi- ty across the land-use systems. The soil $C$ stock varied both in terms of soil depth and different land use. The maximum soil $\mathrm{C}$ stock in $T$. candida plantation was probably due to high root biomass and $\mathrm{C}$ exudation rate, whereas Horticulture garden reported the minimum among the studied land use. The greatest fluxes of soil $\mathrm{C}$ resulted from the conversion of native forests to other land use. Therefore, maintaining adequate soil organic matter content, proper soil structure and other soil properties are obligatory for the sustainability of the land-use systems. The present study suggests that $T$. candida can play a vital role in improving the soil $C$ stock in degraded land uses of Mizoram. A further study on the rate of soil organic matter decomposition across the land-uses will improve the understanding of soil carbon dynamics along with a soil profile and the potential response of soil carbon to land-use change.

\section{Conflict of interest}

The authors declare that they have no conflict of interest.

\section{REFERENCES}

1. Aboim, M.C.R., Coutinho, H.L.C., Peixoto, R.S., Barbosa, J.C. \& Rosado, A.S. (2008). Soil bacterial community structure and soil quality in a slash-and-burn cultivation system in Southeastern Brazil. Applied Soil Ecology 38, 100-108. https://doi.org/10.1016/j.apsoil.2007.09.004

2. Ali, S., Begum, F., Hayat, R. \& Bohannan, B.J.M. (2017). Variation in soil carbon stock in different land uses and altitudes in Bagrot Valey, Northern Karakoram, Acta Agriculturae Scandinavica, Section B-Soil \& Plant Science 67, 551-561. https://doi.org/10.1080/09064710.2017.1317829

3. Arevalo, C.B.M., Bhatti, J.S., Chang, S.X. \& Sidders, D. (2009). Ecosystem carbon stocks and distribution under different land-uses in north central Alberta, Canada. Forest Ecology and Management 257, 1776-1785. https:// doi.org/10.1016/j.foreco.2009.01.034

4. Batjes, N.H. (1996). Total Carbon and Nitrogen in the Soils of the World. European Journal of Soil Science 47, 151-163.

5. Blais, A.M., Lorrain, S., Plourde, Y., \& Varfalvy, L. (2005). Organic Carbon Densities of Soils and Vegetation of Tropical, Temperate and Boreal Forests. In: Tremblay A., Varfalvy L., Roehm C., Garneau M. (eds) Greenhouse Gas Emissions - Fluxes and Processes. Environmental Science. Springer, Berlin, Heidelberg. pp 155-158

6. Blake, G.R. \& Hartage, K.H. (1986). Bulk Density. In: Klute, A., Ed., Agronomy Society of America and Soil Science Society of America, Madison, 363-376.

7. Don, A., Schumacher, J. \& Freibauer, A. (2011). Impact of tropical land-use change on soil organic carbon stocks: A meta-analysis. Global Change Biology 17 (4), 1658-70. https://doi.org/10.1111/j.1365-2486.2010.02336.x

8. Economic Survey Mizoram, (2016-17.) Government of Mizoram. Planning \& Programme Implementation Department (Research \& Development Branch) pp. 243-245.

9. Emiru, N. \& Gebrekidan, H. (2013). Effect of land use 
changes and soil depth on soil organic matter, total nitrogen and available phosphorus contents of soils in Senbat watershed, Western Ethiopia. ARPN Journal of Agricultural and Biological Science 8, 206-212.

10. Forest survey of India (2017). The State of Forest Report, Forest Survey of India, Ministry of Environment and Forests, Dehradun, India.

11. Guo, L.B. \& Gifford, R.M. (2002). Soil carbon stocks and land use change: a meta analysis. Global Change Biology 8, 345-360

12. Haghdoost, N., Akbarinia, M. \& Hosseini, S.M. (2013). Land-use change and carbon stocks: A case study, Noor Country, Iran. Journal of Forestry Research 24, 461-469. https://doi.org/10.1007/s11676-013-0340-2

13. Iqbal, M.A., Hossen, M.S. \& Islam, M.N. (2014). Soil organic carbon dynamics for different land uses and soil management practices in Mymensingh. Proceedings of 5th International Conference on Environmental Aspects of Bangladesh; Bangladesh. pp 16-17.

14. Laganiere, J., Angers, D.A. \& Pare, D. (2010). Carbon accumulation in agricultural soils after afforestation: a meta-analysis. Global Change Biology 16, 439-453. https://doi.org/10.1111/j.1365-2486.2009.01930.x

15. Lehmann, J., Da Silva Cravo, M. \& Zech, W. (2000). Organic matter stabilization in a Xanthic Ferralsol of the central Amazon as affected by single trees: chemical characterization of density, aggregate, and particle size fractions. Geoderma 99, 147-168. https://doi.org/10.1016/S00167061(00)00070-7

16. Manpoong, C. \& Tripathi, S.K. (2019). Soil properties under different land use system of Mizoram, North East India. Journal of Applied and Natural Science. 11(1): 121 125. https://doi.org/10.31018/jans.v11i1.1999

17. Manpoong, C., Hauchhum, R. \& Tripathi, S.K. (2020a). Soil fertility and root carbon exudation in Tephrosia candida (Roxb.) DC hedgerows under Sloping Agricultural Land Technology in Mizoram, northeast India. Journal of Tropical Agriculture, 58 (1): 12-21.

18. Manpoong, C., De Mandal, S., Bangaruswamy, D.K., Perumal, R.C., Benny, J., Beena, P.S., Ghosh, A., Kumar, N.S. \& Tripathi, S.K. (2020b). Linking rhizosphere soil biochemical and microbial community characteristics across different land use systems in mountainous region in Northeast India. Meta Gene, 23, 100625. https:// doi.org/10.10 16/j.mgene.2019.100625

19. Maurya, B., Singh, V., Dhyanib, P. \& Kashyap, S. (2014). Impact of altitudes on soil characteristics and enzymatic activities in the forest and Fallow lands of Almora District of Central Himalaya. Octa Journal of Environmental Research 2, 1-9.

20. McDaniel, M.D., Grandy, A.S., Tiemann, L.K. \& Weintraub, M.N. (2016). Eleven years of crop diversification alters decomposition dynamics of litter mixtures incubated with soil. Ecosphere 7(8): e01426. https:// doi.org/10.1002/ecs2.1426

21. McKinley, D.C., Ryan, M.G., Birdsey, R.A., Giardina, C.P., Harmon, M.E., Heath, L.S., Houghton, R.A., Jackson, R.B., Morrison, J.F., Murray, B.C., Patakl, D.E. \& Skog, K.E. (2011). A synthesis of current knowledge on forests and carbon storage in the United States. Ecological Appli- cations 21(6):1902-24. https://doi.org/10.1890/10-0697.1

22. Ovung, E.Y., Kumar, K.S., Manpoong, C., Tripathi, S.K., Khanduri, V.P. \& Singh, S.K. (2020). Influence of land use pattern on soil quality in a steeply sloped tropical mountainous region, India. Archives of Agronomy and Soil Science 1-21. https://doi.org/10.1080/03650340.2020.1 858478

23. Singh, S.L., Sahoo, U.K., Gogoi, A. \& Kenye, A. (2018). Effect of Land Use Changes on Carbon Stock Dynamics in Major Land Use Sectors of Mizoram, Northeast India. Journal of Environmental Protection 9, 1262-1285. https:// doi.org/10.4236/jep.2018.912079

24. Turner, J., Lambert, M.J. \& Johnson, D.W. (2005). Experience with patterns of change in soil carbon resulting from forest plantation establishment in eastern Australia. Forest Ecology and Management 220, 259-269. https:// doi.org/10.1016/j.foreco.2005.08.025

25. Van der Werf, G.R., Morton, D.C., DeFries, R.S., Olivier, J.G.J., Kasibhatla, P.D., Jackson, R.B., Collatz, G.L. \& Randerson, J.T. (2009). $\mathrm{CO}_{2}$ Emissions from Forest Loss. Nature Geoscience 2, 737-738. https://doi.org/10.1038/ ngeo671

26. Walkley, A. \& Black, A. (1934). An Examination of the Degjareff Method for Determining Soil Organic Matter and a Proposed Modification of Chromic Acid Titration Method. Soil Science 37, 29-38.

27. Wang, Z.P., Han, X.G. \& Li, L.H. (2008). Effects of grassland conversion to croplands on soil organic carbon in the temperate Inner Mongolia. Journal of Environmental Management 86, 529-534. https://doi.org/10.1016/ j.jenvman.2006.12.004

28. Wapongnungsang, Hauchhum, R. \& Tripathi, S.K. (2017). Litter Decomposition Vis-a-Vis Carbon and Nitrogen Dynamics of Tephrosia candida Components in Different Fallow Periods Following Shifting Cultivation in Mizoram. Indian Journal of Ecology 44, 791-796.

29. Wapongnungsang, Manpoong, C. \& Tripathi, S.K. (2018). Changes in Soil Fertility and Rice Productivity in Three Consecutive Years Cropping under Different Fallow Phases Following Shifting Cultivation. International Journal of Plant \& Soil Science 25(6): 1-10. https://doi.org/10.9734/ IJPSS/2018/46087

30. Wei, X.R., Shao, M.G., Gale, W. \& Li, L.H. (2014). Global pattern of soil carbon losses due to the conversion of forests to agricultural land. Scientific Reports, 4, 4062. https://doi.org/10.1038/srep04062

31. Yan, Y., Tian, J., Fan, M., Zhang, F., Li, A., Christie, P., Chen, H., Lee, J., Kuzyakov, Y. \& Six, J. (2012). Soil organic carbon and total nitrogen in intensively managed arable soils. Agriculture, Ecosystems \& Environment 150, 102-110. https://doi.org/10.1016/j.agee.2012.01.024

32. Yang, Y.H., Chen, Y.N., Li, W.H. \& Wang, Y. (2018). Effects of land use/cover change on soil organic carbon storage in the main stream of Tarim River, China. Enviromental Science 36, 2784-2790.

33. Zhang, K., Dang, H., Tan, S., Cheng, X. \& Zhang, Q. (2010). Change in soil organic carbon following the 'Grainfor-Green' programme in China. Land Degradation \& Development 21, 16-28. https://doi.org/10.1002/ldr.954 